\title{
Partidos, facciones, y el debate electoral de 1844-1845: el escenario político del debut de Polk
}

\author{
Guadalupe Paz* \\ ESCUELA PAUL H. NITZE DE ESTUdios INTERNACIONALES AVANZADOS \\ UNIVERSIDAD JOHNS HOPKINS
}

\begin{abstract}
Análisis del debate electoral de 1844-1845 en Estados Unidos, que muestra las complejas circunstancias políticas que

llevaron a la elección de James $\mathrm{K}$. Polk a la presidencia. Su postulación y después elección, fueron resultado de las profundas divisiones económicas y sociales entre el Norte y

el Sur del país; un examen detallado de las fuerzas que definieron la elección es útil para entender los hechos y las circunstancias que más tarde llevaron a la guerra con México.
\end{abstract}

\section{INTRODUCCIÓN}

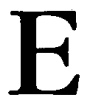

1 proceso de expansión hacia el oeste que tuvo lugar en Estados Unidos a mediados de los años cuarenta, en el siglo XIX, ocurrió en una época en que los asuntos de la

*Quiero agradecer a Piero Gleijeses su apoyo y consejo durante la preparación de este ensayo. Asimismo, expreso mi gratitud a los colegas y amigos que se tomaron el tiempo para leerlo, brindarme sugerencias, y hablarle de él a otras personas interesadas -en tal sentido agradezco especialmente a Federico Reyes Heroles, Sergio Aguayo, José Luis García Aguilar, Eduardo López, Arturo Clares y Russell Crandall. [Traducción de Rafael Vargas.] política nacional que se debatían adquirían un perfil más complejo a medida que los intereses se volvían cada vez más regionales y que -en medio de ese creciente regionalismo- los par. tidos políticos comenzaban a identificarse con ideologías coherentes. Esa situación creó una complicada serie de divisiones dentro de la Unión, separando al Norte del Sur, al Este del Oeste, a los demócratas de los whigs, y uniendo a veces a facciones conducidas por distintos intereses, cuando las cuestiones regionales rebasaban las ideologías de los partidos. La nominación y elección de James K. Polk a la presidencia 
fue consecuencia de esa división regional. Este ensayo brinda un análisis del debate electoral de 1844 y explica las circunstancias y complejas realidades políticas que llevaron a su elección. Un examen detenido de los asuntos que dominaron esa contienda electoral permite una comprensión más profunda de los acontecimientos que más tarde llevaron a la guerra con México, y proporciona al lector herramientas útiles para abordar desde un ángulo interesante cuestiones hipotéticas que han dejado perplejos a los historiadores durante décadas. Por ejemplo: si el Partido Demócrata se hubiese derrumbado, si Martin van Buren hubiese sido el candidato presidencial de los demócratas, o si Henry Clay hubiese triunfado bajo el membrete de los whigs, ihabría cambiado drásticamente el curso de la historia de Estados Unidos? ¿Se habría evitado la guerra con México? ¿Sería Estados Unidos la misma entidad geográfica que es hoy o se habría precipitado la guerra civil antes de la adquisición de Texas, Nuevo México, California y Oregón?

La controversia regional se volvió más intensa con el resurgimiento del tema de la esclavitud. La elección presidencial de 1844 ilustra claramente cuáles eran las fuerzas que dominaban el escenario político, en un momento en que un renovado impulso en favor del expansionismo y un creciente sentimiento de "Destino Manifiesto" se entretejían con intereses económicos y sociales contrastantes, divididos de manera muy notable entre el Norte y el Sur. Esa división regional era tan pronunciada que la candidatura de Polk fue un esfuerzo de último minuto para establecer un candidato de avenencia para el Partido Demócrata. El Sur apoyaba de manera decidida la anexión de Texas, y a final de cuentas ese asunto le costó a Van Buren la nominación presidencial. Es útil echar un vistazo al debate que tuvo lugar durante esa contienda electoral para comprender cuán profundas eran las divisiones regionales y cuán significativo era, en tal coyuntura, el problema de la posible disolución de la Unión -quince años antes del estallido de la guerra civil.

Los whigs, cuya fuerza se localizaba de manera más notable en el noreste, y cuyos principios se asociaban de manera más estrecha con intereses manufactureros y mercantiles, todavía estaban recuperándose del fiasco político derivado de la presidencia "accidental" de Tyler. No obstante, estuvieron cerca de obtener la mayoría del voto popular en la elección presidencial de 1844, pero sólo consiguieron 105 votos electorales contra los 170 de Polk. El candidato abolicionista del Partido Libertad, James Birney, logró dividir la oposición a los demócratas y obtuvo $2.3 \%$ del voto popular, quitándole suficientes votos a Clay en Nueva York como para permitir que los demócratas ganaran ese decisivo estado. ${ }^{1}$

Este ensayo muestra cómo los conflictos regionales que prevalecieron a mediados de la década de 1840 tuvieron un impacto importante sobre dos

${ }^{1}$ Rozwenc y Bender, Making, 1972/1978, vol. I, hasta 1877 , p. 480 . Para ver un análisis simplificado de los resultados electorales a través de los votos popular y electoral, visítense los Multieducator History Archives, U. S. Elections, 1844, en www.multied.com. 


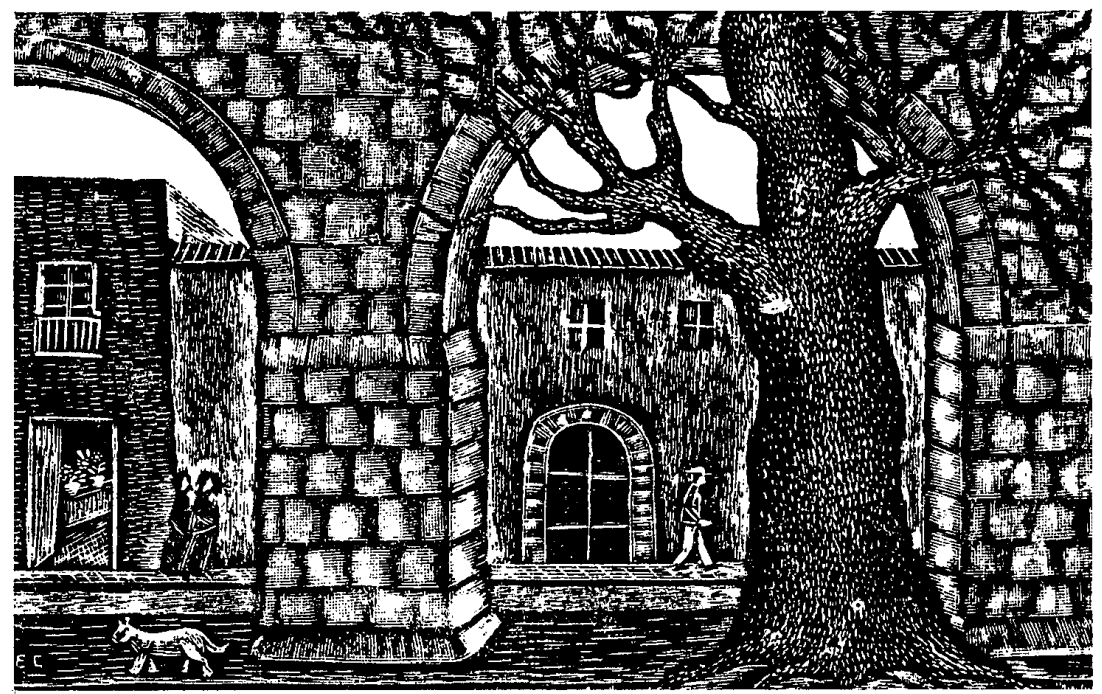

de los temas dominantes en el debate electoral de 1844 relativos al comercio exterior y a las relaciones diplomáticas de Estados Unidos: la tarifa arancelaria y la anexión de Texas. Ambos asuntos moldearon las plataformas electorales de los principales candidatos: Polk y Clay.

Aunque el problema de Oregón tenía gran importancia en aquella época, sobre todo una vez que se convirtió en tema de campaña de los demócratas en 1844, es un asunto que este ensayo no analiza en profundidad. Ello se debe al interés fundamental de la autora por estudiar los temas de la política interna estadunidense que pueden considerarse como antecedentes directos de la guerra con México y que describen de la manera más precisa el ánimo del país y los intereses que con el paso del tiempo condujeron a la guerra. La plataforma expansionista de Polk mostraba claramente su ambición de apropiarse de Texas y Oregón. Aunque ambas cuestiones territoriales merecen una cuidadosa atención en el contexto del "Destino Manifiesto" y la expansión hacia el Oeste, la autora opina que el debate sobre la anexión de Texas describe de manera más precisa las disputas regionales que dividieron al país a propósito de la esclavitud y de la expansión hacia el Oeste durante el periodo 1844-1845; ese es el tema que se relaciona de manera directa con la posibilidad de guerra con México. El problema de Oregón es analizado brevemente al final de este ensayo. 
Presentación de los temas del debate: la tarifa arancelaria y la anexión de Texas

La tarifa arancelaria era un asunto importante por sus implicaciones económicas y comerciales. El impulso al desarrollo industrial en el noreste iría a desempeñar un papel central en la construcción de una fuerte base económica sobre la que habría de depender el desarrollo del país a largo plazo. La tarifa arancelaria también era un tema que dividió fuertemente al Norte y al Sur, aunque los dos principales partidos representaban, por lo menos en principio, posturas opuestas. Los demócratas alegaban que una tarifa arancelaria proteccionista sólo servía para ahondar las desigualdades del pueblo estadunidense; los whigs defendían la idea de que la protección redundaría en crecimiento comercial y movilidad social, dando a Estados Unidos independencia y poderío económicos.

Si bien la anexión de Texas fue resuelta por el presidente saliente, Jonhn Tyler en la víspera de la toma de poder de Polk, precipitó un candente debate que no se refería solamente a las implicaciones de la anexión o no anexión, sino también a una variedad de cuestiones que estaban sumamente influidas por el cisma regional entre el Norte y el Sur. Ese debate se centró en asuntos como la extensión territorial de la esclavitud, una supuesta amenaza extranjera, la posibilidad de comenzar o heredar una gieerra con México y, finalmente, la constitucionalidad de la anexión mediante un tratado, en vez de una resolución conjunta del cuerpo legislativo, además de la posible violación del tratado de amistad y comercio con México.

\section{La relevancia e importancia de las fuentes primarias elegidas}

Es importante destacar que la prensa posindependentista de Estados Unidos llegó a dividirse en campos políticos y que los periódicos eran abiertamente proselitistas. Richard Allen Schwarzlose describe en una de sus obras la naturaleza de la "prensa partidaria":

El movimiento de la prensa partidaria surgió con la primera administración presidencial de George Washington, dominó el periodismo hasta las décadas de 1830 y 1840 , y siguió siendo evidente durante la guerra civil. A lo largo y ancho de la nueva república, ligada por una política postal de libre intercambio de periódicos, una red de periódicos grandes y pequeños saludaba las causas de los federalistas, whigs y republicanos, mientras que una contrarred ensalzaba, en secuencia, las virtudes de los antifederalistas, los demócratas-republicanos y los demócratas. Obviamente, esa mutua dependencia demostró ser benéfica tanto para la naciente prensa como para los nuevos partidos, pero también sirvió a la nación al brindarle canales de comunicación por medio de los cuales el distante simpatizante de partido desarrolló plataformas partidarias e identificó y midió el apoyo con que contaban los candidatos a puestos públicos [...] Desbordantemente sesgada, la prensa partidaria libraba una guerra perpetua con todo tipo de artilleria literaria contra todos aquellos que se oponían al par- 
tido, línea política o personaje político favorecidos. $^{2}$

Hay que tener en cuenta que fue durante las décadas de 1830 y 1840 cuando surgió la denominada "prensa de a centavo" (así llamada porque los voceadores vendían los periódicos en las calles por uno o dos centavos). Anteriormente, los periódicos eran relativamente caros y casi exclusivamente leídos por las elites políticas y económicas de Estados Unidos, de modo que por lo general se vendían por medio de suscripciones y su circulación cotidiana promediaba apenas 1000 ejemplares. Con la imprenta de vapor y otras innovaciones tecnológicas que incrementaron la capacidad de imprimir, junto con una creciente clase media, la prensa de a centavo

entretuvo, informó e instruyó a los nuevos lectores de esa época sobre el mundo a su alrededor, brindándoles un sentimiento de identidad de clase e introduciéndolos asimismo a las comunidades políticas y de negocios a las que se estaban incorporando en números cada vez mayores. ${ }^{3}$

En las principales áreas de debate durante la contienda presidencial de 1844, la cuestión de los derechos del Sur y de la posible disolución de la Unión tenía un peso importante. El radical punto de vista sureño dominaba en el debate electoral, particularmente con respecto a las divisiones intraparXXII.

${ }^{2}$ Schwarzlose, Newspapers; 1987 , pp. xxI-

${ }^{3}$ Ibid., pp. XXIII-XXII. tidarias Norte-Sur. Esa postura está claramente ilustrada en el diario demócrata sureño Mercury, editado en la ciudad de Charleston, en el estado de Carolina del Sur. Fundado en 1822, el Mercury era considerado como la contraparte más importante frente a los intereses del Norte, y en especial en relación con los abolicionistas. Con John A. Stuart como editor durante el periodo 1844-1845, el Mercury apoyaba la candidatura presidencial de John C. Calhoun, de Carolina del Sur, y fue sólo después de que Polk y su aliado político y candidato a la vicepresidencia, George Dallas, fueron nominados, que el diario les brindó apoyo, aunque de manera más o menos renuente. La posición e importancia del Mercury como conciencia del Sur se refuerza por el hecho de que, antes y durante la guerra civil, Robert Barnwell Rhett, un conocido fire-eater (provocador) que defendía la secesión y condenaba los movimientos antiesclavistas $-\mathrm{y}$ a quien algunos consideraban el "padre de la secesión"-, era el editor del periódico. El Mercury también ilustra claramente las disputas entre el Norte y el Sur en la medida en que publicaba y respondía de manera regular a los editoriales y cartas publicados por el Globe, el órgano demócrata oficial con sede en Washington D. C. Después de que Polk asumió el poder, deshizo los lazos que quedaban entre el órgano demócrata oficial y la facción de Van Buren al sustituir el Globe, editado por Francis Blair, por el Daily Union de Washington, editado por Thomas Ritchie, de Virginia.

El debate entre whigs y demócratas hace una distinción más clara entre los 
principios de los partidos, y sin embargo también ilustra con claridad las divisiones económicas y sociales entre el Norte y el Sur -por ejemplo, las relacionadas con la esclavitud. La mejor fuente para mostrar la perspectiva de los whigs es el órgano oficial del partido, el National Intelligencer, con sede en Washington. D. C., y fundado en 1800 . Además de divulgar los puntos de vista oficiales del partido, el Intelligencer reimprimía de manera regular una variedad de artículos y editoriales de diversos diarios whigs, y sus editoriales eran influyentes y ampliamente citados por otros periódicos de la misma tendencia.

Por último, una buena fuente de información general primaria que abarca al conjunto del país es el Niles' National Register, un semanario fundado en 1811 y publicado en Baltimore, Maryland. El Niles' Register se convirtió en una destacada fuente de información, hechos y estadísticas nacionales, y reproducía artículos y editoriales de un buen número de diarios con distintos puntos de vista.

\section{Introducción a la dinámica de la arena política en la década de 1840}

En el contexto de las divisiones regionales, y basándose principalmente en información primaria obtenida de los tres periódicos elegidos -el Mercury, de Charleston; el National Intelligencer, y el Niles' National Register-, este ensayo sugiere que los intereses sureños eran la fuerza dominante que orientaba a la política nacional de Estados
Unidos a mediados de la década de 1840. No obstante, los intereses nortenoos prevalecieron y brindaron un marco político competitivo que requería de un grado de avenencia entre intereses sumamente divergentes.

La importancia de esa controversia regional y la fuerza política del Sur se ve ilustrada por la afirmación de que,

debido a que el Sur controlaba al Partido Demócrata, y debido a que el Partido Demócrata (usualmente) controlaba el gobierno federal, el Sur estuvo "montado en la silla" durante toda la época jacksoniana. ${ }^{4}$

Empero, la situación en 1844 era frágil. El resultado de la contienda electoral de ese año reflejaba la fuerza del cabildeo sureño, y sin embargo las divisiones regionales continuaron ahondándose. Los años intermedios de la década de 1840 marcan un periodo clave en la política de Estados Unidos, cuando el destino del país estaba en las manos de un electorado profundamente dividido.

\section{EL LEGADO JACKSONIANO Y LAS FACCIONES POLÍTICAS}

El contexto en el que se desenvolvió la elección presidencial de 1844 está estrechamente asociado con el legado jacksoniano, la definición de los partidos y las facciones políticas que se desarrollaron en esa época y el creciente regionalismo que finalmente desembo. có en la guerra civil. Aunque la plata-

\footnotetext{
${ }^{4}$ Ashworth, "Agrarians", 1983, p. 238.
} 
forma política de Andrew Jackson y su coalición no estaba claramente definida cuando asumió el poder en 1829 , en términos generales se apegaba a la filosofia de un gobierno nacional con poderes limitados. En ese sentido, el Partido Demócrata atraía a un grupo de votantes que consideraba al gobierno federal como una posible amenaza a los derechos de los estados. Ello era especialmente importante en el Sur, dado que la institución de la esclavitud y los intereses económicos de la región la separaban del Norte, mientras que la percepción del peligro que representaban los intereses manufactureros y las fuerzas antiesclavistas, dio pie a tendencias cada vez más radicales que abogaban por la acción estatal e incluso por la secesión como estrategias viables.

John Calhoun, quien había sido reelecto como vicepresidente durante el primer periodo de Jackson, se convirtió en un amargo rival del entonces secretario de Estado, Martin van Buren, cuando ambos se posicionaron para competir por la futura sucesión. Esa rivalidad, junto con las marcadas opiniones de Calhoun sobre los derechos sureños, influyeron en su intervención durante la crisis de "anulación"s en 1832-1833, y con el tiempo lo llevaron a separarse del gobierno jacksoniano. Aunque al principio Calhoun había abogado a favor de las tarifas arancelarias y

\footnotetext{
${ }^{5}$ El término "anulación" (en inglés "nullification") se refiere a la doctrina estadunidense que defendía el derecho de un estado de la Unión a declarar nula y sin efecto (en territorio propio) una ley federal. La crisis de anulación en 1832-33 tuvo lugar cuando Carolina del Sur
}

de las mejoras internas, la postura antiproteccionista tan obstinadamente adoptada por su nativa Carolina del Sur lo llevó a promover el principio de anulación. Defendió los intentos de anulación de Carolina del Sur relativos a las tarifas arancelarias de 1828 y 1832 , y el conflicto entre él y los jacksonianos se ahondó considerablemente. La agresiva respuesta de Jackson a la gente de Carolina del Sur -el Decreto de Fuerza que autorizaba al presidente a emplear la fuerza militar si era preciso para recaudar los impuestos arancelarios-, así como la tarifa arancelaria de avenencia aprobada por el Congreso en 1833, fueron indicativas, por una parte, de la fragilidad de la Unión y, por otra, del carácter cada vez más regional de la política.

Entre tanto, el reorganizado Partido Nacional Republicano, aludiendo a la era independentista y protestando contra lo que consideraba como la "tiranía ejecutiva" de las medidas y posturas políticas de Jackson, se convirtió en el Partido Whig. Aunque los whigs habían perdido la elección de 1836 contra Van Buren, heredero de Jackson y de su orientación política, era evidente que se convertían en una fuerza política creciente. Ello se debía sobre todo al hecho de que la época posterior a la elección de Jackson fue un periodo en que el Partido Demócrata comenzó a identificarse más claramente con una

declaró nulas las tarifas arancelarias de 1828 y 1832 y amenazó con separarse de la Unión si el gobierno federal insistía en cobrar los impuestos arancelarios por la fuerza. La crisis fue resuelta en 1833 mediante una tarifa arancelaria de avenencia. 
filosofía agraria y durante el cual se exhibieron las divisiones dentro del partido, lo que llevó a la separación de aquellos que no podían aceptar sus principios rectores y, por tanto, al debilitamiento del partido.

Las conservadoras políticas económicas de Jackson dejaron también una herencia importante, ya que su "guerra contra el Banco de Estados Unidos" y su oposición al empleo de papel moneda dividieron al electorado y lo enemistaron con los empresarios que dependían del sistema financiero vigente, en tanto que hacía concesiones a los intereses "agrarios". El problema de la tarifa arancelaria siguió siendo central en el debate político que siguió a ese periodo de "democracia jacksoniana". Los estados sureños continuaron pujando por tarifas arancelarias más bajas y "libre comercio", en tanto que el Norte clamaba por una tarifa arancelaria proteccionista.

Volviendo a la crisis de anulación de principios de la década de 1830 , el caso de Carolina del Sur es de particular interés durante el debate electoral de 1844, ya que ese estado era una de las principales fuerzas en el movimiento en pro de una convención de estados sureños que hiciera valer derechos y promoviera acciones estatales en caso de que el Sur siguiera siendo "oprimido por los excesivos impuestos del gobierno federal y castigado por la operación de un sistema injusto e inconstitucional". 6 El siguiente fragmento de un editorial del Mercury de Charleston describe con claridad la división Norte-

\footnotetext{
${ }^{6}$ Brutus, "Is the State pledged?", Mercury, 2 de agosto de 1844, Charleston.
}

Sur, así como la posición de Carolina del Sur:

luego de haber dirigido una petición y de haber protestado hasta que nuestra paciencia se ha agotado y nuestra dignidad se ha visto comprometida, qué remedio, qué recurso nos queda, excepto el que ya habíamos advertido al pueblo de Estados Unidos que emplearíamos: ila interposición de la autoridad soberana del estado, para impedir la imposición de ese sistema dentro de nuestras fronteras! [...] Ante estos dos grandes asuntos [la tarifa arancelaria y la anexión de Texas][...] me temo que es muy claro que disentimos de los demócratas del Norte, tanto como disentimos de los whigs. ${ }^{7}$

El asunto de la esclavitud era fundamental en este debate. Se consideraba que la esclavitud era esencial para la seguridad y sobrevivencia del Sur, pues su economía dependía de la mano de obra que proporcionaba esa muy im. portante parte de su población.

El llamado a una acción sureña conjunta para proteger la institución de la esclavitud y defender los derechos e intereses sureños dio pie al debate -tanto en el Sur cuanto en el Norte- sobre la posible disolución de la Unión y, en particular, sobre la cuestión de Texas. En una declaración emitida por un comité organizado en Alabama, se sacan a la luz los siguientes asuntos:

Se nos acusará de urdir un plan, me. diante la creación de una convención sureña, para disolver la Unión. Negamos y rechazamos tal imputación. Nuestro objeto es su preservación [...]

${ }^{7}$ Ibid. 


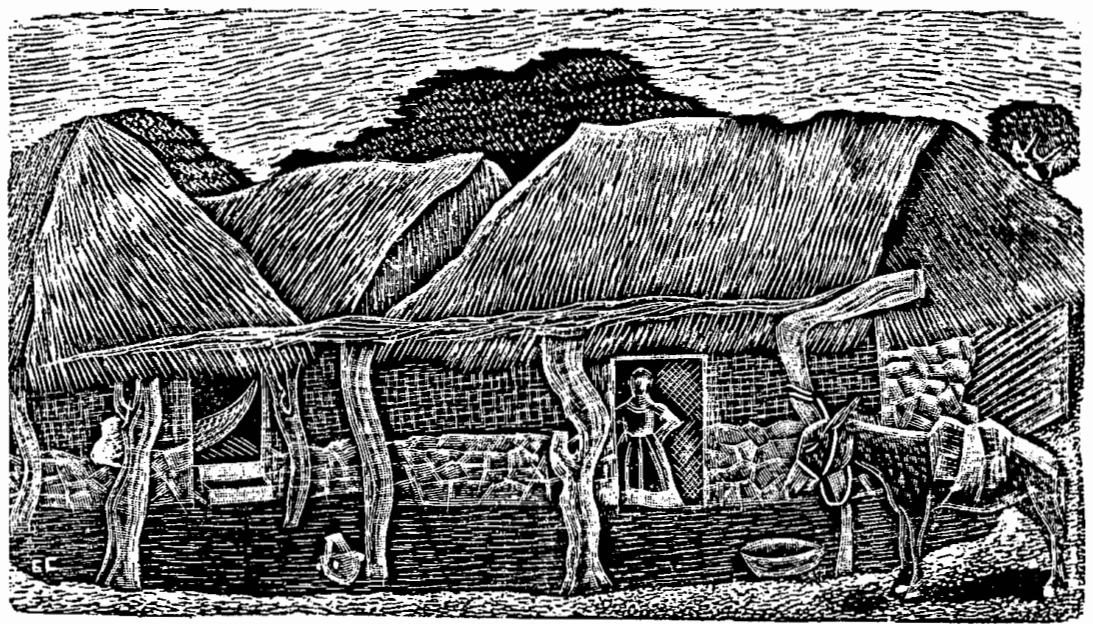

En la asamblea que proponemos, los estados sureños invitarán a una discusión serena, abierta, franca y moderada acerca de su derecho, bajo el pacto de la Unión, a la entera seguridad de la institución de la esclavitud doméstica, dentro de sus respectivos límites, la cual debe estar exenta de la hostil legislación de los estados libres; de la no menos hostil acción de las naciones extranjeras, violatoria de acuerdos -estipulados que sólo pueden alcanzarse por medio del poder soberano de la nación entera, $y$ de todo debate en el Congreso. ${ }^{8}$

8 "To the people of slaveholding states", petición y resoluciones de Russell County, Alabama, en relación con el llamado a una Convención de Estados Sureños, tal como aparecí́ impresa en el Mercury, de Charleston, el 3 de julio de 1844 .
La "amenaza" presentada por naciones extranjeras se refiere especialmente a la Gran Bretaña (a la que comúnmen. te se hacía referencia al decir Inglaterra), pues en el Sur muchos la consideraban como promotora de la abolición con la intención de socavar el poderío económico y comercial de los estados agrícolas esclavistas. También durante ese tiempo, un acalorado debate en el Congreso indicó el inminente rechazo de la 21a. Resolución [mordaza].

${ }^{9}$ Entre 1836 y 1844 se aprobó una serie de "resoluciones mordaza" que prohibían la consideración de peticiones antiesclavistas en el Congreso. Después de la creación de la Socie. dad Antiesclavista Americana, en 1833, el Congreso se vio inundado por peticiones abolicionistas. El rechazo de la última resolución mordaza fue conseguido en 1844, gracias al lideraz- 
El mismo comité de Alabama declaró lo que sigue en relación con el asunto de la esclavitud:

No deben temer una discusión sobre esta institución social y política, ya sea en sus relaciones estadísticas o morales. En cuanto a la riqueza que añade a los recursos de la nación, o su anterior eficacia para civilizar y cristianizar a millones de seres de otra raza, muchos de los cuales de otro modo se hallarían ahora en un estado de barbarie caníbal en vez de ser lo que de hecho ahora son, con la sola excepción de los agricultores blancos de nuestro país: los campesinos mejor alimentados, mejor vestidos, con menos carga de trabajo y más contentos que hay en el mundo. Es derecho exclusivo de los estados sureños el decidir en qué momento estarán listos esos trabajadores para una relación social más elevada. Un derecho que nunca cederán a otros, excepto a punta de bayoneta. ${ }^{10}$

Como veremos en el siguiente análisis del debate sobre la anexión de Texas, el tema de la esclavitud era central, $y$ vale la pena señalar que, aunque había habido una serie de intentos para adquirir Texas desde comienzos de la década de 1820 , empezando con el gobierno de John Quincy Adams, el problema de la esclavitud hacía cada vez más difícil realizar tal propósito. Adams, quien había insistido en tratar de retener Texas cuando se negociaba el Tratado de Florida en 1819, se opuso a la anexión en 1845.

go de John Quincy Adams y Joshua Giddings en la Cámara de Representantes.

10 "To the people of slaveholding states", Mercury, 3 de julio de 1844.
El ambiente politico en 1844-1845: montando el escenario

Aunque los dos principales partidos tenían diferencias internas en términos de estructura y opinión, los demócra. tas y los whigs mantenían posiciones claramente distintas sobre los temas fundamentales del debate. No obstante, con respecto a la ideología, ambos partidos eran ambiguos. Sólo estaba claro que los demócratas favorecían la promoción de los ideales de un gobierno democrático. Los whigs, por su parte, se dividían entre el ala conservadora, que se oponía a los ideales democráticos, y el ala liberal, que a veces se asemejaba a la posición de los demócratas. El único asunto que unía al Partido Whig era su fuerte oposición a Jackson y sus seguidores.

Aunque el cisma entre ambos partidos era importante desde la perspectiva de la identificación popular con los asuntos y los principios políticos, las cuestiones económicas y financieras dominaron el debate. La cuestión bancaria, por ejemplo, era central y controversial después del Pánico de 1837. Los demócratas, a pesar de algunas divergencias de opinión, se unieron bajo la posición oficial del partido en favor de una tesorería independiente; los whigs se unieron en contra, proponiendo en vez de ello un banco nacional. Desde el punto de vista de la retórica partidaria, los demócratas se alinearon con las políticas de "dinero duro" o "bard-money" (que abogaban en favor del uso de monedas [generalmente de oro] para transacciones, o bien, de la garantía de que el papel moneda fuera cambiable por moneda 
dura) en contra de los whigs y de los "suaves" (quienes apoyaban el uso irrestricto de papel moneda, al que se referían como "dinero suave" o "softmoney").

Entre otros asuntos financieros de importancia que dividieron a los partidos, estaba la política agraria. Los demócratas apoyaban una política liberal con generosos derechos de apropiación agraria para los colonos, mientras que los whigs defendian una política conservadora opuesta a los derechos de apropiación agraria y favoreciendo en cambio la distribución de los ingresos por ventas de tierras para mejoras internas y educación entre los estados. El tema de la tarifa arancelaria también era central en el debate, especialmente después de que la tarifa de avenencia había expirado en 1842. La posición demócrata oficial era oponerse a una alta tarifa arancelaria proteccionista que "violaba los derechos igualitarios del pueblo y beneficiaba a una minoría de comercios y manufacturas". Sin embargo, la plataforma demócrata sí permitía una tarifa arancelaria fiscal y, como puede verse en la campaña de Polk, recurría cuando era necesario a un principio de preferencialidad que brindara en consecuencia cierto grado de protección. Los whigs, por otra parte, fomentaban una economía diversificada, autosuficiente, que según afirmaban sólo podía alcanzarse por medio de una barrera arancelaria proteccionista.

Los retos más importantes para el sistema de partidos políticos de aquella época se derivaban de las divisiones regionales y de la diversidad geográfica de la Unión. Los estados sureños estaban separados en grado importante a causa de la institución de la esclavitud y de la defensa de los derechos estatales sureños; los estados orientales se caracterizaban por un desarrollo urbano e industrial; en tanto, el Oeste era todavía una zona fronteriza con vastas porciones de tierras indómitas a la cual el sobreendeudamiento y el limitado desarrollo había llevado a grandes problemas con los bancos. Esas divisiones y la conciencia de una posible disolución de la Unión, ya fuese impulsada por diferencias en los intereses económicos o por los problemas que podían surgir de la expansión hacia el Oeste, fueron elementos importantes durante el debate de $1844{ }^{11}$

\section{LA ELECCIÓN DE 1844: ¿DEMÓCRATAS CONTRA WHIGS O SUR CONTRA NORTE?}

La Convención Demócrata de mayo de 1844 , durante la cual habría de elegirse al candidato presidencial, mostró cuán hondas eran las divisiones en el seno del partido. Los dos principales candidatos, Van Buren y Lewis Cass, repre. sentaban dos fuertes facciones. Van Buren era considerado como el candidato del "dinero duro", apoyado por demócratas del norte que se oponían a la extensión territorial de la esclavitud y por ende a la anexión de Texas. Cass representaba el punto de vista del viejo Noroeste y defendía el expansionismo y los principios de la libertad indivi-

\footnotetext{
11 Para un análisis detallado de las ideologías de los partidos en Estados Unidos durante la era jacksoniana, véase Ashworth, "Agrarians", 1983.
} 
dual o "soberanía popular" (especialmente en relación con la esclavitud) y de un gobierno con poderes limitados.

Esta escisión intrapartidaria era tan pronunciada que las dos facciones se detestaban mutuamente casi tanto como detestaban a los whigs. La dinámica de la convención de Baltimore está descrita en una carta anónima publicada en el Niles' National Register:

Mientras los amigos de Van Buren se afanaban convocando a sus fuerzas contra los desorganizados sureños, los otros candidatos y sus respectivos amigos se hallaban no menos ocupados fabricando estratagemas contra cada uno de los demás. Los amigos del coronel Johnson estaban tan celosos de la creciente influencia del señor Cass como los amigos de este último estaban ansiosos por doblegar al primero ante la furia de los partidarios de Van Buren. A fin de cuentas la Convención asumió el carácter de un juego despiadado, con cada una de las facciones decidida a destruir a la otra. ${ }^{12}$

Aunque los partidarios de Van Buren fueron la facción dominante hasta 1844, el que se opusiera a la anexión inmediata de Texas le costó la nominación. La primera ronda de votaciones se inició con siete candidatos, y Polk no se presentó sino hasta la octava ronda, cuando los únicos candidatos que quedaban eran Van Buren y Cass. En la novena votación Polk fue elegido como el candidato demócrata con base en una plataforma que apoyaba la

${ }^{12}$ Anónimo, "The secret history of Polk's nomination at Baltimore disclosed", Niles' $\mathrm{Na}$ tional Register, 26 de octubre de 1844, p. 123. inmediata "reanexión" de Texas (y la "reocupación" de Oregón) y se oponía vigorosamente a la tarifa arancelaria proteccionista. ${ }^{13}$

De esta manera, si la nominación de Polk no fue una medida de avenencia, por lo menos mostró ser la opción más aceptable para la mayoría de los demócratas. Sin embargo, durante el transcurso de la campaña electoral las facciones del partido encontraron la manera de debatir.

\section{El debate sobre la tarifa arancelaria}

El Sur se mostraba un tanto receloso en relación con las expectativas de que los intereses sureños ganaran terreno aun cuando Polk ganara la elección, ya que, desde su perspectiva, los demócratas de la legislatura habían traicionado sus promesas, así como los principios del partido en favor de los intereses norteños. Después de que la tarifa arancelaria de 1842 fue promulgada en el Congreso por una mayoría whig, los demócratas radicales esperaban que la nueva legislatura, con una mayoría de 60 votos demócratas en la Cámara de Representantes, la revocaran inmediatamente, como habían asegurado. En vez de ello, lo que revocaron durante las sesiones que siguieron en 1843 1844 fue la 21a. Resolución, que excluía las peticiones de abolición, en tanto

\footnotetext{
${ }^{13}$ Para un análisis de la votación durante las nueve rondas durante la Convención Demócra ta de Baltimore, véase "Balloting for presidential candidate", Niles' National Register, 1 de junio de 1844, p. 211.
} 
que la tarifa arancelaria permaneció intacta.

El consecuente resentimiento por parte del Sur fue inevitable. Según el Mercury, de Charleston, tal resentimiento desempeñó un papel importante en la nominación de Polk a expesas de Van Buren:

La confianza del Sur en la democracia norteña y sus líderes se vio cimbrada. Se consideró que eran un poco mejores que los whigs en cuanto a sus principios, pero más bien peores en cuanto a sus declaraciones, puesto que éstas claramente se hicieron para engañar y traicionar [...] Los representantes de la democracia norteña fueron dejados de lado, y el señor Polk resultó nominado -un sureño y supuesto representante de la democracia sureña. Se creía que con su nominación habían triunfado los buenos principios, y el Partido Demócrata, con las resoluciones de Baltimore de 1840 y la anexión de Texas sobreañadida, entró a la contienda presidencial de 1844. De esa manera, la traición de la democracia norteña en relación con la tarifa y la 21a. Resolución ayudó a derrocar a Van Buren, en tanto que una supuesta identificación con los simples y honestos principios de la democracia sureña le dieron al señor Polk la nominación a la presidencia. Por lo menos así era como se contemplaban las cosas en el Sur. ${ }^{14}$

No obstante, Polk decepcionaría a sus radicales partidarios sureños muy poco después.

14 "The causes of Mr. Polk's nomination to the presidency", Mercury, 31 de marzo de 1845, Charleston. Con "democracia norteña" y "sureña" se refiere a los demócratas del Norte y del Sur, respectivamente.
En una carta que habría de convertirse en objeto de escándalo, dirigida al señor Kane, de Filadelfia, Polk anunció su posición ligeramente cambiada en relación con la tarifa arancelaria, buscando, evidentemente, ganar el respaldo de los demócratas norteños:

Estoy a favor de una tarifa arancelaria fiscal; una que, bien administrada, le brindará a la Tesorería una cantidad suficiente para sufragar los gastos del gobierno. Hasta ahora, al ajustar los detalles de una tarifa arancelaria fiscal, he aprobado aranceles preferentes lo suficientemente moderados como para que produzcan la cantidad de ingresos requerida, y al mismo tiempo proporcionen en consecuencia una razonable protección a nuestra industria doméstica. Soy contrario a una tarifa que sea sólo para protección, y no de carácter fiscal. ${ }^{15}$

En declaraciones públicas anteriores había afirmado:

[En varias ocasiones] he reconocido $\mathrm{mi}$ oposición al acta arancelaria [de 1842] del pasado Congreso whig por tener un carácter sumamente proteccionista y porque sus autores no la pensaron como una medida de ingreso fiscal [...] Los intereses del país -y especialmente de los estados productores y exportadores- requieren que se le revoque, y que se restauren los principios del acta de la tarifa de avenencia de $1833 .{ }^{16}$

Este episodio despertó las más vivas sospechas de los radicales, y alimentó

15 "Presidential candidates -The tariff", Mercury, 5 de agosto de 1844, Charleston.

16 "The tariff", Mercury, 2 de julio de 1844. Charleston. 
las divisiones entre el Norte y el Sur dentro del partido demócrata.

Refiriéndose a esto, John Stuart, editor del Mercury de Charleston, expresó su opinión sobre Polk y la posición de Carolina del Sur antes de la elección presidencial.

No podemos evitarlo, y difícilmente lo lamentaremos, si Carolina, salvaguardando sus promesas y la Constitución, pone en aprietos al señor Polk en sus negociaciones electoreras con los opresores de aquélla. ¿Puede él quejarse de dureza, cuando en primer lugar no tuvo escrúpulos para poner al estado de Carolina en ridículo al acudir a los proteccionistas después de que aquél había saludado la nominación de Polk como la del hombre del libre comercio? Polk tendrá nuestro voto porque está con nosotros en el asunto de Texas, aunque tampoco en ese respecto le tenemos tanta confianza como le tendríamos si hubiese sido sincero en lo tocante a la tarifa arancelaria. ${ }^{17}$

Polk, en efecto, recibió un apoyo considerable por parte de los estados sureños. Después de la elección, el Mercury de Charleston afirmó:

[Las] declaraciones del señor Polk sobre la tarifa arancelaria... [en su] carta al señor Kane, citadas ahora en nuestra contra, han provocado en verdad una amarga y pesarosa decepción a todos los partidarios honestos del libre comercio, proyectando una sombra de duda sobre los resultados de la contienda presidencial entera. En su carta el señor Polk emplea un lenguaje sobre el tema

"John A. Stuart, "Our position and our pledges", Mercury, 7 de agosto de 1844, Charleston. de la tarifa arancelaria que pudo ser, y fue utilizado, para mostrar que él apoyaba la protección. Con esa carta el señor Buchanan [reconocido senador demócrata por Pennsylvania] demostró para plena satisfacción de [sus conciudadanos] pensilvanos que el señor Polk era un mejor promotor de la tarifa proteccionista que el señor Clay. Así pues, nos hemos visto obligados a suponer o bien que el señor Polk había abjurado de sus principios, o bien que había jugado un juego taimado para conciliar, en favor suyo, a esa misma porción de los demócratas cuyas triquiñuelas y perfidia habían dado pie a que el pueblo exigiera un cambio de gobernantes, y por quienes había tal desconfianza como para destruir al señor Van Buren. La gente del Sur se siente alentada [...] con todas las promesas de que la evidente falsedad del Partido Demócrata en lo referente a la tarifa y a la 21a. Resolución fue solamente resultado de un mero cálculo, en vista de la inminente elección. Y que una vez terminada, volverían a encontrarse de nuestro lado, listos para cumplir sus promesas [...] La disposición a la esperanza y a la confianza prevaleció por encima de todas las precauciones que aconsejaba la experiencia, y el señor Polk recibió el voto de ocho de los doce estados del Sur. ${ }^{18}$

De este modo, los radicales sureños esperaban que su apoyo a Polk se tradujera más tarde en un cambio de curso en la política nacional, uno más favorable a sus intereses. Existía una evidente conciencia de los embrollos de la política electoral, así como muestras de esperanza, y a veces de escepticis-

18 "What we were promised from Mr. Polk's election", Mercury, 2 de abril de 1845, Charles. ton. 


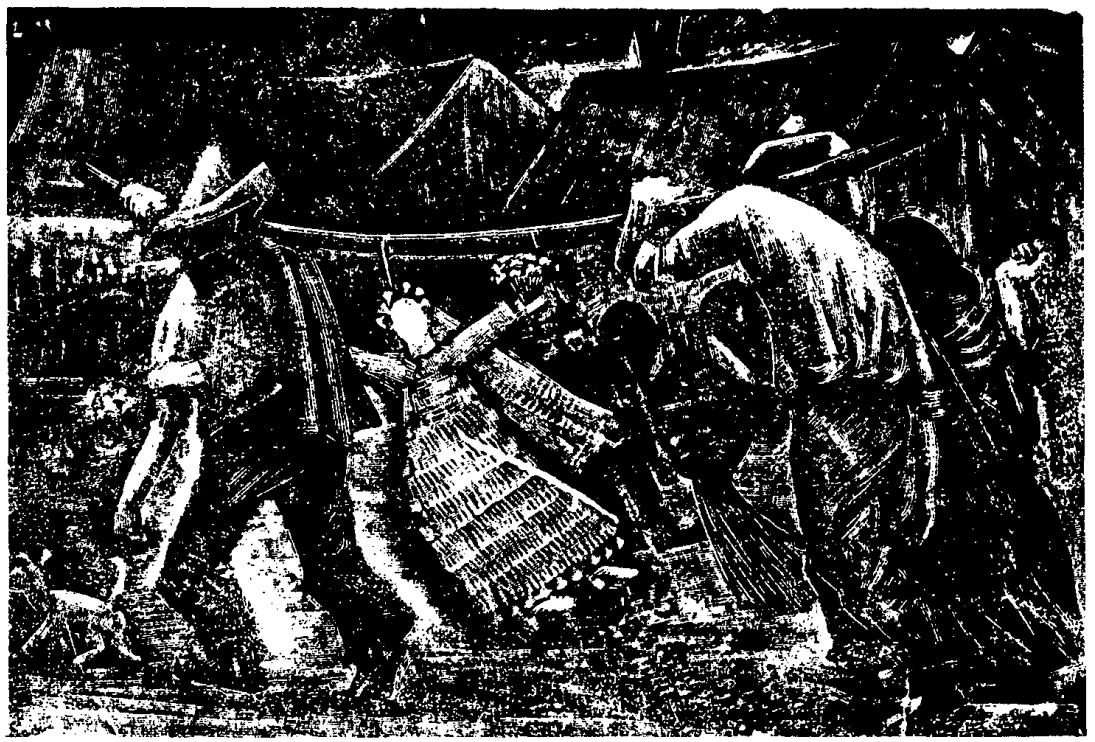

mo, en que a fin de cuentas Polk demostraría su compromiso con los intereses del Sur.

El resentimiento hacia los demócratas del Norte, expresado por los demócratas del Sur, se arraigaba en la añeja creencia de que, con el objeto de obtener el respaldo electoral necesario para sobrevivir en la contienda política, los norteños manipulaban engañosamente los intereses de los sureños.

El columnista del Mercury de Charleston conocido como "Catón" explica:

Estos aliados nuestros del Norte [...] encontraron útil cortejar no sólo a los proteccionistas sino también coquetear de manera inconfundible con los aboli- cionistas. Revocar o siquiera reducir la tarifa [de] 1842 los malquistaría con aquellos de sus partidarios en casa que tenían la desdicha de interesarse en hacer inversiones protegidas, y que tan desdichadamente se hallaban situados que, a menos que se rescindiera la 21a. Resolución, no podrían responder por los votos de su otra clase de votantes, cuyos meticulosos escrúpulos acerca de la esclavitud habían sido desde hace mucho tiempo motivo de profunda pesadumbre para ellos [...] "iAcaso no comprenden el truco?", nos susurraban. "Tenemos que conseguir los votos de esos conciudadanos, o no podremos volver para ayudarlos a ustedes." $[\ldots]$ Pero si una gran parte del partido sobre el cual estamos invitados a edificar nuestras esperanzas es tan poco firme -poco firme en cuanto a la tarifa, y poco firme 
en la cuestión de la esclavitud-, y si nuestro conocimiento de esa falta de firmeza no proviene de conjeturas nuestras, sino que es fruto de la experiencia [...] ino estamos obligados a reconocer que nuestras expectativas han sido completamente defraudadas? [...] Cuando escucho a alguien abrigando alguna esperanza en el Partido Demócrata, me siento obligado a concluir que deliberadamente ha decidido que es mejor ser tomado por un tonto que ser obligado a ejercer la discreción de un hombre prudente, $o$ asumir la resolución de un hombre valiente. ${ }^{19}$

Así, la afiliación al partido no era vista como un medio seguro para obtener la representación buscada por quienes pertenecían a éste -los intereses regionales llevaban a los políticos a cortejar a las diversas facciones $y$ a actuar de acuerdo con ello.

En ese sentido, los partidos funcionaban como máquinas electorales. Por ejemplo, en relación con la elección de Polk, el gobernador demócrata Silas Wright, de Nueva York, argumentaba que

ninguno de los candidatos presidenciales podría haber esperado, ni por un momento, obtener una mayoría de los votos del estado [de Nueva York] si sus afirmaciones no hubiesen estado basadas en la promesa de que favorecía la permanencia de las actuales leyes de tarifas arancelarias, sin modificaciones sustanciales. ${ }^{20}$

19 "The state of South Carolina vs. the Charleston Meeting -Cato", Mercury, 2 de julio de 1844, Charleston.

${ }^{20}$ Así aparece citado en "The tariff", Mercury, Charleston, 17 de enero de 1845.
Aunque Nueva York estaba profundamente dividido, es muy probable que la ambigua posición de Polk en relación con la tarifa haya incrementado el apoyo que se le brindaba en ese estado.

No obstante, entre los demócratas sureños la novedosa ambigüedad de Polk sobre el particular fue considerada como una traición a aquellos que lo habian apoyado por su posición original. El Mercury de Charleston respondió a esto de manera indignada:

Así que este es el final de todo nuestro bullicio; fue a cambio de 'las actuales leyes de tarifas arancelarias, sin modificaciones sustanciales' -es decir, las leyes vigentes o algo igual de malo-que nos desgañitamos por iPOLK! y iDALLAS! [...] Ahora hasta la cuestión de Texas, que nosotros ya dábamos por segura, depende de un arreglo, isi no es que acaba por arreglarse en favor de los whigs! $^{21}$

Pero sus alternativas habían sido limitadas, y a fin de cuentas demostraron su fe en los principios del partido, ya fuera porque en verdad habían depositado sus esperanzas en los resultados que traería una victoria demócrata, o porque veían su elección como el menor de dos males.

El National Intelligencer, periódico de los whigs, sostenía una visión más moderada sobre las alternativas políticas relacionadas con la tarifa de 1842 :

Este sistema proteccionista es parte esencial de la política whig que, en todos los casos, busca el desarrollo de

${ }^{21}$ Ibid. 
los recursos del país, físicos e intelectuales, para protección de todos los intereses y para procurar, por los medios adecuados, la felicidad del pueblo y la prosperidad de la nación. Por otra parte, la política del locofoquismo, ${ }^{22}$ o jaco. binismo, es la peor que cualquier ciudadano podía adoptar, sea como medio para mejorar su prosperidad, extender sus libertades o refinar su moral y sus costumbres $[\ldots]$ y la situación a la que este país se vio reducido en 1840 , después de la exitosa guerra de este partido contra el Banco de Estados Unidos, prueba que su influencia traicionera es la misma en todas las épocas y climas y bajo todas las formas de gobierno. Su naturaleza es esencialmente destructiva [...] Muchos podrían desear una reforma del sistema bancario o una modifcación de la tarifa pero, entre reformar y destruir -entre modificar y abolir- hay un mundo de diferencia. La más absurda de todas las reformas es, sin duda, abolir lo que es bueno porque no es perfecto. ${ }^{23}$

La posición demócrata sureña era en verdad radical e inflexible; sin embargo, en el noreste, los demócratas a veces se oponían oficialmente a la reducción de tarifas arancelarias. Asimis-

\footnotetext{
${ }^{22}$ Los "locofocos" eran un ala radical del Partido Demócrata. Recibieron ese nombre cuando los miembros del partido en Nueva York apagaron las farolas de gas para desalojar a los radicales de una reunión para presentar nominaciones; los radicales respondieron encendiendo velas con los nuevos fósforos autoinflamables conocidos como "locofocos", y procedieron a nominar su propia lista de candidatos. Después los enemigos políticos del Partido Demócrata aplicarían burlonamente ese nombre a todos los demócratas.

23 "The protective system", National Intelligencer, 29 de agosto de 1844 , Washington.
}

mo, la división regional afectaba al Partido Whig en la medida en que cada vez era más difícil para los whigs del Sur -con excepción de los de Luisiana, donde la industria cañera necesitaba protección- apoyar con firmeza a sus colegas del Norte.

Desde el punto de vista de las implicaciones comerciales de la política de tarifas arancelarias, los estados agricultores del Sur eran los más afectados por el proteccionismo y, por ende, se identificaban fuertemente con los ideales del "libre comercio". Los países extranjeros interesados en el mercado estadunidense, Gran Bretaña y Francia en especial, apoyaban la postura en favor del libre comercio. No obstante, en el Noreste se consideraba que la protección por medio de tarifas era necesaria para mantener a flote los intereses de las industrias manufactureras.

El Intelligencer mostró preocupación porque le parecía percibir un interés extranjero (bastante real) en la victoria de Polk gracias a su supuesta plataforma de "libre comercio". Lo que sigue, además de un fragmento de una carta escrita por un inglés, es una cita tomada de un diario francés publicado en Nueva York, el Courrier des États Unis:

Entre los problemas políticos que han de ser resueltos con la elección presidencial hay uno que no se nos puede pedir que contemplemos con indiferencia y neutralidad: el problema de la tarifa es sobradamente un problema franco-estadunidense, y debe quedar en nuestro terreno de discusión. Es nuestro derecho emplear todas nuestras energías para obtener el triunfo del libre comercio, y zafarnos del pesado yugo que por dos años ha pesado sobre el 
comercio extranjero, y en especial sobre el de Francia. ${ }^{24}$

Los whigs emplearon esta declaración para alegar que ese tipo de interés extranjero en los asuntos políticos internos de Estados Unidos era evidencia de que países como Francia y Gran Bretaña estaban claramente interesados en arruinar las industrias agrícola y manufacturera del país, incorporando al debate de esa manera el tema de una amenaza externa contra los intereses de Estados Unidos. Con respecto al artículo del Courrier el Intelligencer respondió:

deseamos que la gente de este país vea y comprenda el interés que esas naciones [Gran Bretaña y Francia] tienen en derrocar nuestro sistema proteccionista actual. Pero si SU interés es verlo postrado, NUESTRO interés es mantenerlo $y$ defenderlo. Si el señor Polk llega a la presidencia, tenemos su declaración de que actuará de manera inflexible en contra de la tarifa de 1842, y bien pode. mos esperar la destrucción de nuestras manufacturas y de nuestro mercado para productos agrícolas. Si el señor Clay es elegido $[. .$.$] esos grandes intereses se-$ rían sostenidos y fomentados [...] iPueden nuestros granjeros y mecánicos, y nuestros ciudadanos en general, tener motivos más poderosos para defender la tarifa arancelaria que el testimonio francés e inglés aquí aducido, de que interesa a esos países abolirla??

Así, el debate de la tarifa arancelaria no solamente era central desde la perspectiva de la política comercial de Esta-

24 "American interest and clay, or foreign interest and Polk", National Intelligencer, 29 de octubre de 1844, Washington.

${ }^{25}$ Ibid. dos Unidos, sino que también reflejaba las divisiones regionales entre dos sistemas económicos muy diferentes: los manufactureros del noreste y los "agricultores" del Sur. Tanto demócratas como whigs se hallaban divididos internamente por los intereses norteños y sureños pero, aunque las tensiones regionales eran fuertes, quedaban contenidas dentro del sistema de partidos; se identificaba a los demócratas con el libre comercio y a los whigs con el proteccionismo, y en forma general se entendía que la victoria de Polk significaría una eventual reducción de las tarifas arancelarias, en tanto que la de Clay significaría que los impuestos arancelarios serían fijados en función de metas proteccionistas más que fiscales.

\section{Texas y la anexión: "necesidad" contra "intereses regionales"}

El estudioso Jesse Reeves afirma que la guerra entre Estados Unidos y México no fue consecuencia de la anexión de Texas a Estados Unidos, sino que, más bien, esos acontecimientos fueron dos fases distintas de la expansión hacia el suroeste. ${ }^{26}$ En efecto, la anexión de Texas y la guerra con México fueron iniciativas separadas motivadas por distintos intereses durante dos administraciones diferentes. También se cree generalmente que Polk le habría declarado la guerra a México sin importar si los mexicanos habían iniciado las hostilidades o no, y más bien basado en la disposición de México para ne-

${ }^{26}$ Reeves, American, 1907, p. 58. 
gociar la venta de California y Nuevo México a Estados Unidos. Sin embargo, el debate público de 1844-1845 subrayó la preocupación de que la anexión de Texas pudiera derivar en una guerra con México.

El debate en torno de la anexión de Texas también reflejaba la naturaleza regional de los temas económicos y políticos que dominaron la elección presidencial de 1844 y que permearon tanto la política interna como la externa durante ese periodo. Las cuestiones relativas a la constitucionalidad de la anexión mediante un tratado o por una resolución conjunta del Congreso, junto con la cuestión del tratado de amistad y comercio entre los Estados Unidos y México y su potencial violación a causa de la anexión de Texas, tan sólo fueron parte del debate. Hubo otras consideraciones en el debate -a veces de mayor importancia- que se centraron en la prolongación de la esclavitud, la posible disolución de la Unión, y la amenaza de otras potencias extranjeras (principalmente Inglaterra) en caso de que Texas se convirtiera en territorio de una tercera nación.

El asunto de la esclavitud creaba tal desacuerdo político que obstaculizaba la expansión hacia el Oeste. Como senala Reeves, "sin la introducción de la cuestión de la esclavitud, la oposición a la anexión de Texas probablemente nunca hubiese sido el asunto político que fue en 1844". ${ }^{27}$ Afirma, además, que las opiniones proesclavistas de Tyler se sumaron a su deseo de anexar Texas porque temía que la abolición de la esclavitud en esta región constituiría

${ }^{27}$ Ibid., p. 59. una seria amenaza para la esclavitud en todo el Sur. El tratado de anexión propuesto por Tyler primero fue rechazado, en junio de 1844 , pero su decisión de resolver el asunto lo condujo a forzar la anexión mediante una resolu. ción conjunta.

La constitucionalidad de tal medida fue ampliamente cuestionada. Cuando el asunto estaba siendo considerado en el Congreso, el Intelligencer afirmó:

Esta decisión de la Cámara de Representantes implica, en nuestra opinión, el ejercicio de un poder que, de pertenecer a Estados Unidos, pertenece, en la primera fase (de la anexión) exclusivamente a aquellas ramas del gobierno que están investidas con la autoridad para hacer contratos con potencias extranjeras, y no puede ser ejercido por el Congreso, como se ha propuesto, sin violar la Constitución. O bien Texas es un poder independiente, capaz de disponer su propio destino, o no lo es. Si lo es, es necesario hacer un convenio (tratado) con aquél, con el consentimiento de dos tercios del Senado, en actuación conjunta con el ejecutivo. Si no lo es, se trata de una provincia de México -nación con la que Estados Unidos está en paz-, y sólo puede ser anexada, o admitida en esta Unión, ya sea con o sin las condiciones especificadas en la Resolución Conjunta, mediante un convenio o tratado con México, formado del modo prescrito por la Constitución en estos breves pero explícitos términos: "Él [el presidente] tendrá el poder, por y con el consentimiento del Senado, para bacer tratados, a condición de que concurran dos terceras partes de los senadores."28

${ }^{28}$ National Intelligencer, 27 de enero de 1845, Washington. 


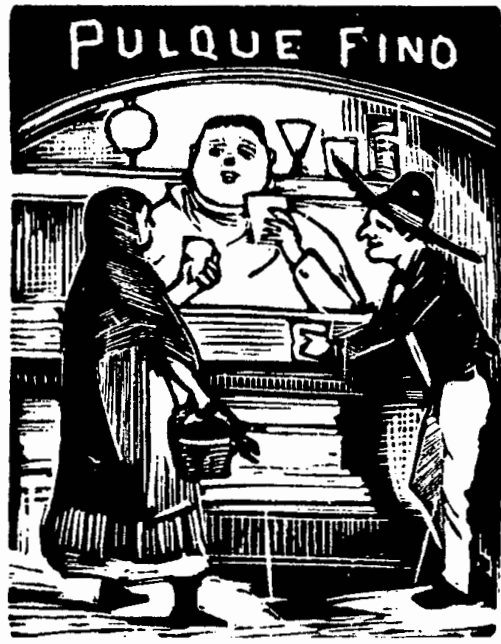

El Mercury de Charleston respondió con un ataque sobre la "constitucionalidad" de las iniciativas del Norte contra las instituciones del Sur:

En sus esfuerzos por mantener a Texas fuera de la Unión, los whigs en el Congreso, en especial los de la región manufacturera, están embargados por un gran respeto hacia la Constitución [...] Pero sea como fuere, es un insulto el querer citarle la Constitución al Sur para mantener a Texas fuera de la Unión. Los hombres del Sur deberían responderos: "Vosotros habéis quebrantado la Constitución con respecto a nuestras instituciones, y nosotros no la tendremos en cuenta para mantenerlas [...] $\mathrm{Si}$ tal acto es inconstitucional, es justificable dada vuestra perfidia al violar primero la Constitución en lo que a noso. tros concierne sobre este vital asunto. Con ese acto tan sólo recuperaremos el poder y la seguridad por los que ingresamos a la Unión, virtudes que la Constitución estipula que la Unión ha de brindar. En lo que atañe a este asunto vosotros habéis destruido la Constitución. eVosotros vais a citarnos la Constitución? [...] Constitucional o no, tendremos a Texas."29

No obstante la oposición norteña, al final la resolución conjunta fue aprobada, dejándole a Polk un conjunto de problemas que sin duda habrían de surgir después de la medida -los principales, entre ellos, eran la controversia sobre los términos de la anexión y la posible guerra con México.

Durante el debate por la anexión, trece whigs -John Quincy Adams entre ellos- promulgaron un manifiesto en oposición a la anexión de Texas, en el que abordaban los asuntos de la esclavitud y la desunión:

No vacilamos en afirmar que la anexión, efectuada por cualquier tipo de acta o procedimiento del gobierno federal o de cualquiera de sus departamentos, sería idéntica a la disolución. Sería una violación de nuestro pacto nacional, de sus objetivos, de sus designios, y de los grandes principios elementales que intervinieron en su formación, de un carácter tan profundo y fundamental, y sería un intento de eternizar una institución y un poder tan injustos en sí mismos [la esclavitud], tan dañino a los intereses, y tan aborrecible a los sentimientos de la gente de los estados libres que, en nuestra opinión, no sólo conduciría inevitablemente a la disolu.

29 "Texas and the Constitution", Mercury, 16 de enero de 1845, Charleston. 
ción de la Unión, sino que la justificaría totalmente. ${ }^{30}$

En una carta a Daniel Webster, James Hamilton, un antiguo gobernador de Carolina del Sur y ardiente defensor de la "anulación" durante la crisis de 1832, critica el empleo del tema de la esclavitud para oponerse a la anexión de Texas:

El que un estadista como usted mismo, que manifiesta un amor tan cordial por la Unión, juegue el mezquino juego de poner el problema de la esclavitud en la balanza contra los intereses de cada parte de la Unión, es algo por completo indigno de usted. Deberia dejarle eso a su admirable amigo el señor John Quincy Adams, a quien, con un afortunado apodo, el señor [Langdon] Cheves llama el "Anacharies Clootz" [refiriéndose a Anacharsis Cloots] ${ }^{31}$ de Estados Unidos [...] Su Magno Apolo, el señor Clay, nos ha dicho que el problema de la esclavitud nada tiene que ver con las grandes reflexiones nacionales que intervienen en este asunto. No obstante, usted declara que él se opone, con usted, a extender la esclavitud a ese vasto territorio al oeste del Sabina. ¿A quién le hemos de creer? [...] ¿Está usted inventando un

${ }^{30}$ Tal cual se publicó en el Mercury de Charleston. "The cry for disunion", Mercury, 29 de julio de 1844.

${ }^{31}$ La asociación se refiere a Jean-Baptiste Cloots, barón de Val-de-Grâce, un demócrata radical durante la revolución francesa, y miembro del club jacobino. A principios de la década de 1790 , como cabeza de su "embajada de la raza humana", compuesta por unos treintaitantos extranjeros, declaró que el mundo debería adherirse a los ideales democráticos de la revolución, se autonombró a sí mismo "Orador de la Humanidad", y adquirió el seudónimo de "Anacharsis".

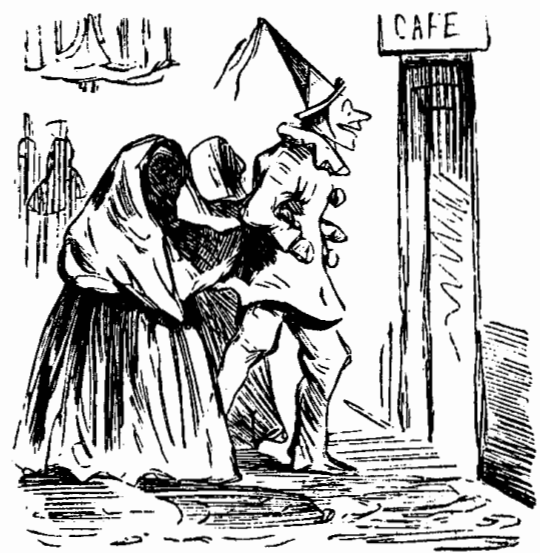

problema sobre la esclavitud para la próxima elección presidencial?[...] Por fortuna es tan improbable que con el solo asunto de la esclavitud logre usted obtener suficiente capital político para ser algo más que concejal de la ciudad de Boston como que su amigo Anacharsis Cloots vuelva a ser presidente de Estados Unidos. ${ }^{32}$

Es evidente que el problema de la esclavitud se había convertido en un arma política de los norteños para oponerse a la anexión. La división regional intensificó el debate sobre Texas e introdujo una controversia adicional relativa al movimiento expansionista.

El Baltimore American planteaba que la expansión territorial de la es-

32 "To the Hon. Daniel Webster -Letter from James Hamilton", Mercury, 14 de octubre de 1844, Charleston. 
clavitud era un asunto de interés sólo para el Sur, y que no valía la pena considerarlo a nivel nacional, y agregaba que las garantías ya provistas por la Constitución deberían bastar para la protección de sus intereses:

La posición asumida por el señor Calhoun y otros anexionistas del Sur en relación con la esclavitud y sus vínculos con la anexión le ha dado un nuevo cariz a la cuestión entera de la esclavitud en este país; $o$, para decirlo de manera más precisa, ha dado lugar a un asunto totalmente nuevo. La discusión a la que ha dado pie no es ya si el gobierno de la Unión habrá de ser rehén de los propósitos del Sur para extender la institución de la esclavitud en nuestro país en vista de que el Sur exige que ello debe hacerse en aras de la seguridad de esa institución. Todo mundo verá que este es por completo un nuevo aspecto del caso. Los defensores más atentos y decididos de los derechos del Sur, hombres que preferirian morir antes que permitir que se interfiera en sus asuntos internos, y que consideran la institución de la esclavitud como parte de su siste. ma social y político contra el cual nadie tiene derecho a objetar pues no le concierne a nadie sino a ellos mismos, advertirán sin embargo, de inmediato, que ha cambiado por completo el panorama que hasta ahora había contemplado la Constitución. En vez de requerir que se observen fielmente las garantías establecidas, la exigencia es que ahora se concedan nuevas garantías. ${ }^{33}$

Este argumento sugiere que el Sur exige que la extensión de la esclavitud

33 "Anexion", del Baltimore American, según su reproducción en el National Intelligencer, 30 de octubre de 1844 . sea considerada como un asunto de política nacional y que los estados no esclavistas de hecho se unan para apoyar la expansión territorial de la esclavitud. Para muchos norteños, la sola idea de no perturbar tal institución donde ya existía, era de hecho una manifestación excesiva de apoyo a los estados esclavistas.

Los razonamientos que planteaban la "necesidad" de la anexión, es decir, que la consideraban indispensable para terminar con una amenaza a la seguridad de Estados Unidos, también eran parte importante del debate. Esa "necesidad" era vista desde la perspectiva de la protección de los intereses y la seguridad de la Unión, la amenaza de potencias extranjeras, e incluso la necesidad de cumplir el destino de Estados Unidos como protector de la libertad en el hemisferio.

Sobre la cuestión de una amenaza extranjera, "Arístides", columnista del Mercury, de Charleston, considera a Gran Bretaña como una amenaza real, y como la única razón que valida la necesidad de procurar la anexión de Texas:

la cuestión de Texas es categóricamente una contienda entre Inglaterra y Estados Unidos; un problema que consiste en si Inglaterra, con su dinero y su política, adquirirá el control de Texas como punto de avanzada en nuestra contra, en nuestro momento de mayor vulnerabilidad en tiempos de guerra, teniendo como aliados al conjunto de salvajes tribus indias vecinas a Texas, o desde el cual, en tiempos de paz, puede socavar nuestras instituciones, procurar para sus posesiones en las Indias Orientales y Texas, mediante la abolición de la 
esclavitud, un monopolio en el comercio de algodón, y promover $y$ fomentar disensiones y desunión entre los diversos intereses y regiones, quebrantar la unión de los estados y destruir al único gran rival que tiene sobre la tierra; o si mediante la anexión de un país y un pueblo que originalmente formaba parte de nosotros se cumplirá nuestro destino en la tierra, cubriendo al continente de América del Norte con nuestras instituciones libres y republicanas y protegiéndolo, en palabras del presidente Monroe, de todo "atrincheramiento europeo en América". ${ }^{34}$

En esta demostración de elocuencia, "Arístides" alude al potencial control de Gran Bretaña sobre Texas como una amenaza a la seguridad de la Unión, pero particulamente del Sur y sus instituciones, a la vez que promueve un sentimiento de solidaridad con el pueblo de Texas y el continente de América acorde con el autoproclamado papel de Estados Unidos como su protector.

Refiriéndose de manera más específica a los intereses sureños, el Mercury de Charleston publicó la siguiente carta:

Considero el rechazo del tratado de anexión como una medida, si no de perversidad, de locura egregia, que sacrifica intereses de gran valor e importancia para toda la Unión, pero particularmente para el Sur y el Oeste; más aún, en relación con el reclamo de la Gran Bretaña -el cual temo que está bien fundado- en cuanto a la libre navegación por el Mississippi y, quizá, en

\footnotetext{
${ }^{34}$ Arístides, "The distinction of parties, No $4^{\prime \prime}$, Mercury, 31 de julio de 1844, Charleston.
}

consecuencia, por sus ríos tributarios. Ese derecho, si existe, le brindaría acceso irrestricto a nuestros territorios y de ese mismo modo llevaría a sus agentes comerciales y a sus emisarios abolicionistas hasta el centro de nuestras ciudades y plantaciones en el corazón mismo de Texas [...] Pero cuando contemplamos, con el lente de lo futuro, las ventajas para el comercio, la navegación, las manufacturas, la agricultura $y$, sobre todo, para la seguridad nacional, y el poder y grandeza que necesariamente derivarían de la adquisición, difícilmente podemos calcular el inmenso valor del beneficio -no sólo para nosotros, sino para toda la Unión- que providencialmente fue puesto en nuestro poder, y que insensiblemente desperdiciamos [...] Inglaterra ya ha enviado a sus emisarios a Texas; después tomará Cuba, bajo un pretexto u otro, como campo adecuado para la abolición. Después mandará sobre el Golfo y sobre el Mississippi[...] Y eso no será todo[...] Si Santa Anna estuviera en condiciones (Dios no lo quiera, pero no sabemos qué intrigas y financiamientos extranjeros podrian brindárselas) de conquistar Texas, qué espectáculo tendria ante sus ojos el pueblo estadunidense [...] ¿Habrán de perecer los valientes y ge. nerosos pobladores de Texas bajo las manos de la hibrida raza de México? Dos terceras partes de ellos son hijos del grandioso Occidente[...] Ninguno de los intereses que dependen de Estados Unidos tiene la mitad de importancia como la prevención de la subyugación de Texas. ${ }^{35}$

35 "Letter to the editor, by judge Langdon Cheves", Mercury, 11 de septiembre de 1844, Charleston. 
El columnista afirma que Texas era absolutamente esencial para la seguridad y los intereses del país, y que tarde o temprano habría de formar parte de la Unión "a cualquier costo". Además, su incorporación a Estados Unidos terminaría con el temor a una intriga extranjera.

Refiriéndose a la idea del "Destino Manifiesto", el National Intelligencer adopta un enfoque diferente:

Bajo el buen Monroe, adoptamos hacia ellas [las repúblicas americanas] un sistema no sólo de la más estrecha amistad, sino de protección, tanta como cupiera justificar. Monroe supo ver que fácilmente podiamos oponer a la liga de reyes de la Europa continental una liga americana de repúblicas, y que éramos, si así lo decidíamos, la cabeza natural de ese sistema. Ello nos conferiría gran seguridad, honor y ventajas. Actuando con métodos siempre justos y afectuosos hacia nuestras hermanas americanas, nos convertiríamos en los árbitros de este continente, en señores de su comercio, y esgrimiríamos, siempre que fuese necesario, su fuerza entera para mitigar el orgullo europeo o controlar las intrigas de las monarquías europeas. Durante los últimos quince años hemos perdido de vista esta noble política. Ahora, sin embargo, el polkismo nos ha hecho adoptar precisamente la política opuesta. Ahora estamos a punto de convertirnos en una nación de asaltantes, iy de comenzar nuestra carrera como tales estrangulando a una república hermana!, precisamente cuando más conciliadores deberíamos haber sido con esa hermana (México), ya que sería por medio de ella que extenderíamos nuestra influencia sobre las demás. Ella, y su buena disposición, son la entrada misma y la avenida que nos daría acce- so a la confianza que iría a erigir y a conducir esa gran liga. ${ }^{36}$

El Intelligencer también defiende la idea de que Estados Unidos es el "árbitro" natural y el protector del continente. No obstante, esa postura no excluye la descripción de la ane-xión de Texas como un asalto contra México, país al que describe como la "entrada" al resto del continente y por ende un país clave en el cumplimiento del "Destino Manifiesto" de Estados Unidos.

El National Intelligencer también consideraba que la posición de Polk era equivalente a la guerra:

La contienda de 1840 , grande como los objetivos que perseguía, estaba confinada a asuntos económicos y constitucionales solamente $-\mathrm{a}$ relaciones industriales, financieras y legales-; podríamos decir, en síntesis, a asuntos internos. La contienda actual incluye todos esos asuntos, y les suma -de la peor manera y con la más aborrecible y demagógica precipitación, imprudencia e injusticia- el alarmante problema de una agresión inmediata, decidida $y$ bostil contra una nación amiga, que indudablemente responderá a esa agresión con la guerra. Pero eso no es todo: si elegimos al señor Polk, no sólo habremos puesto deliberadamente los poderes nacionales en manos de un partido empeñado expresamente en provocar tal problema, sino que no alentaremos otra cosa que un encendido e insensible desafío hacia todas las naciones, y haciendo resonar, mediante su deliberado atropello a México, un men-

36 "Trade with Mexico", National Intelligencer, 25 de septiembre de 1844, Washington. 
saje de rapacería y odio hacia todo el mundo que se interponga en nuestro camino[...] La declaración de guerra, en caso de que el señor Polk sea elegido, será tan indudablemente cierta como cualquier hecho político que alguna vez haya ocurrido. ${ }^{37}$

El Journal of Commerce, de Nueva York, no percibía amenaza alguna de parte de Gran Bretaña o de México:

Es posible que la anexión de Texas produzca una guerra con México, pero creemos que es más bien improbable. Que Texas ingresará a la Unión, es prácticamente seguro, no obstante la oferta de independencia que le ha hecho México en caso de que ella se niegue a formar parte de Estados Unidos. Semejante promesa, a estas alturas, después de que ha alcanzado su independencia sin que México haya podido evitarla, no tiene gran valor. No es fácil predecir con certeza qué camino seguirá México a consecuencia de la anexión-pero creemos que ya ha determinado no entrar en guerra con nosotros a menos que Texas acepte nuestra proposición. Por supuesto que tomará algún tiempo antes de que obtenga la información necesaria para determinar su camino. Entre tanto, tendrá la oportunidad de considerar si ganará algo con una guerra; si no es que, desde todo punto de vista, no estará convirtiendo lo malo en peor[...] El único caso en que México nos obligará a darle una buena paliza proviene del hecho de que está groseramente engañado en relación con el sentir público en Estados Unidos. México cree que el Norte está listo para sepa-

37 "Annexation and war", National Intelligencer, 22 de octubre de 1844, Washington.

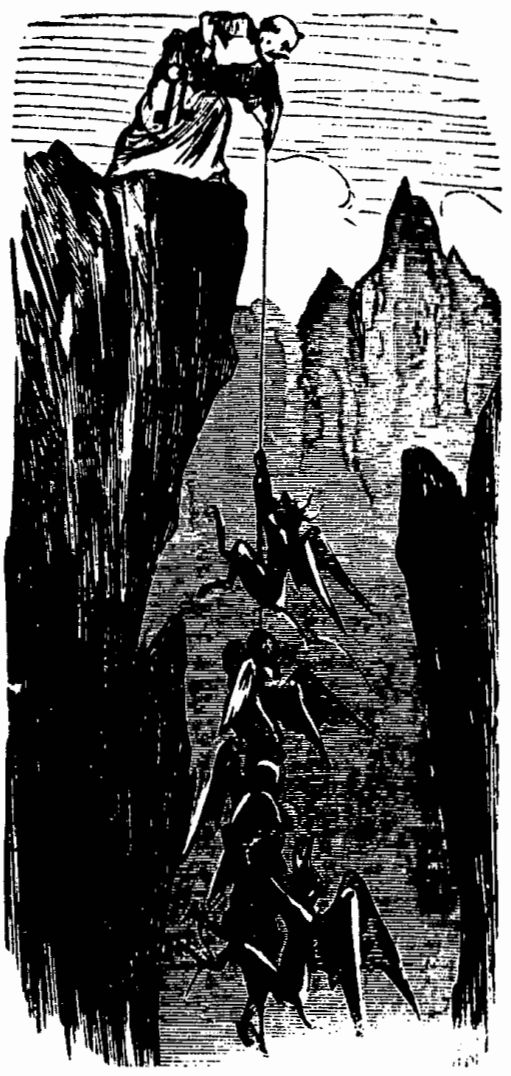

rarse de la Unión a causa de la anexión [...] Está totalmente equivocado. De Inglaterra no hay nada que temer. Preferiria que Texas fuese independiente o que volviera al seno de México, pero no interferirá de ninguna manera excepto mediante negociaciones. El único punto de peligro en nuestras relaciones con Inglaterra es el asunto de Oregón. Pero incluso eso tendría que manejarse 
muy mal $[\ldots]$ para poder provocar una guerra. ${ }^{38}$

El debate sobre Texas también incluía el argumento de que la anexión conduciría inevitablemente a la disolución de la Unión. En una carta del candidato whig publicada en el National Intelligencer, Henry Clay ilustra sus temores con respecto a la anexión de Texas:

Considero que la Unión es una gran sociedad política, y que no deberían admitirse nuevos miembros cuando existe preocupación por el inminente riesgo de su disolución. En lo personal, no tengo ninguna objeción a la anexión de Texas, pero ciertamente no estaría dispuesto a ver que la Unión que hoy existe se disolviera o fuese puesta en un serio peligro por el afán de adquirir Texas. Por los acontecimientos que han ocurrido en Carolina del Sur, es perfectamente claro que existe una facción en ese estado que busca la disolución de la Unión, y que para ese propósito emplea el pretexto del rechazo del abominable tratado del señor Tyler. ${ }^{39}$

Los propios demócratas se hallaban divididos en relación con ese asunto. El Mercury de Charleston critica la postura del Globe, el periódico demócrata de Washington:

El Globe habla otra vez de desunión -indudablemente el signo menos auspicioso que hayamos visto a ûltimas

38 "Wars and rumors of war", tomado del Journal of Commerce, de Nueva York, tal como lo publicó el Mercury, de Charleston, el 1 de mayo de 1845.

39 "Mr. Clay on Texas", National Intelligencer, 8 de agosto de 1844, Washington. fechas a propósito de la anexión. ¿Para qué insistir en ese alegato si no para debilitar la causa de Texas dividiendo y distrayendo a sus amigos, y brindándole ayuda y consuelo a sus enemigos? [...] El tratado podria haber sido aprobado si el Globe y su camarilla no se hubiesen lanzado traicioneramente en oposición de una medida que decían favorecer[...] El juego de aniquilar la medida por medio de sus mejores amigos se repite una vez más. El Globe está muy consciente de la tormenta de indignación que habrá en el Sur si la anexión es derrotada por tan pérfidos medios. ¿Busca entonces ese diario, al vincular siempre esos viles cargos separatistas con cada intento de adquirir Texas, enderezar al Norte contra el Sur y, mediante la unión de los demócratas norteños con los whigs, dejar al Sur -más bien, forzar al Sur a adoptar sus intereses, y su demanda de salvacióncontra la hostilidad combinada de todos los partidos en el Norte? Si es así, es hora de que el Globe hable de la Unión. En verdad que cambiarán los problemas, y el de Texas, importante como es porque se relaciona con el bienestar de toda la Unión, se convertirá en un asunto muy secundario. Que esos absurdos faccionalistras se cuiden con el pasar del tiempo. ${ }^{40}$

El Mercury de Charleston alega que desde el principio los demócratas del Norte habían bloqueado la iniciativa del tratado-primero porque se afirmaba que había una guerra entre Texas y México, y después porque la iniciativa era denunciada como una enorme extensión de la autoridad ejecutiva. Al final, cuando la cuestión fue sometida por

40 "The Washington Globe and annexation", Mercury, 18 de enero de 1845, Charleston. 
resolución conjunta, se dijo que la anexión sólo podía ser adecuadamente efectuada mediante un tratado -manifestando en todo momento su amistosa disposición hacia los intereses sureños.

Ese era el panorama del debate acerca de la anexión de Texas. Los intereses regionales que dividían al país sobre tal asunto presentaban diferentes perspectivas sobre la "necesidad" de la anexión y sobre el impulso expansionista de Estados Unidos, que iban desde la percepción de una amenaza extranjera a la seguridad nacional hasta a perspectivas contradictorias sobre las maneras de cumplir el "Destino Manifiesto" de aquel país.

\section{La negociación sobre Oregón}

La cuestión de Oregón data del siglo XViII, cuando España, Gran Bretaña, Rusia y Estados Unidos habían reclamado cada uno una porción del Pacífico noroeste, con base en la exploración, descubrimiento y asentamientos hechos por sus nacionales. España retiró su reclamo sobre la región con respecto a Gran Bretaña por medio de la Convención de la Sonda Nootka en 1790 , y con Estados Unidos por medio del Tratado Transcontinental de 1819. En 1818 Estados Unidos y Gran Bretaña habían acordado la formal ocupación conjunta del territorio de Oregón, que llegó a ser definido como la región por debajo de los $54^{\circ} 40^{\prime}$ de latitud, por arriba de los $42^{\circ}$ de latitud, y al oeste de la divisoria continental. Rusia retiró su reclamo sobre la región mediante tratados por separado con Gran Bretaña y Estados Unidos en 1824 y 1825 respec- tivamente. Estados Unidos y Gran Bretaña hicieron varios intentos infructuosos para resolver el problema de sus conflictivos reclamos sobre Oregón; sin embargo, cuando el primer acuerdo de ocupación conjunta expiró (1828), no se había alcanzado un nuevo acuerdo, y la ocupación conjunta continuó de manera indefinida.

A comienzos de la década de 1840 , quienes diseñaban la política de Estados Unidos consideraban que era más importante fijar los límites de la frontera noreste que la del noroeste. El entonces secretario de Estado de Estados Unidos, Daniel Webster, temía que al incluir a Oregón en la negociación para resolver la disputa sobre la frontera del noreste pondría en riesgo el éxito de cualquier negociación con Gran Bretaña, a pesar del deseo del presidente Tyler de que se tocara simultáneamente el problema de Oregón. En consecuencia, el Tratado Webster-Ashburton de 1842 entre Estados Unidos y Gran Bretaña solamente sirvió para establecer la frontera entre Maine y New Brunswick, y resolver algunos otros asuntos regionales, incluyendo los derechos de navegación, las leyes de extradición y el establecimiento de un sistema naval conjunto.

En vista de las décadas de ocupación conjunta del territorio de Oregón por Estados Unidos y Gran Bretaña, y de la amenaza planteada por la posibilidad de una guerra con una gran potencia como Gran Bretaña, Estados Unidos actuó con comedimiento para evitar que cualquier acto imprudente pudiera ser considerado por los británicos como algo abiertamente beligerante. La plataforma política de Polk 


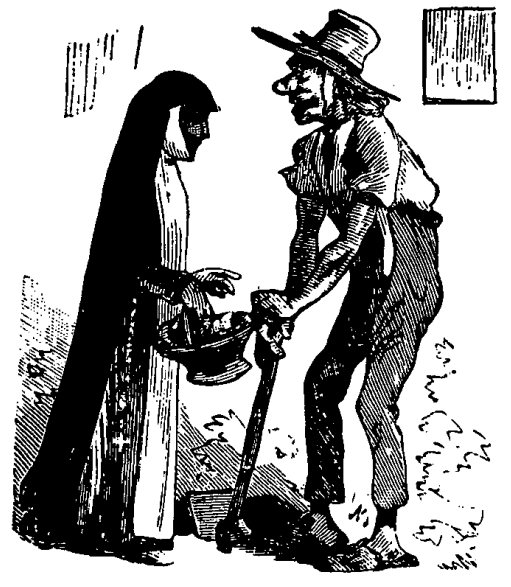

en 1844, que abogaba por la "reocupación" de todo el territorio de Oregón -como lo expresaban sus lemas de campaña "Cincuenta y cuatro-cuarenta o guerra" y "Oregón en su totalidad o nada"-, marcó una desviación de esa cuidadosa postura.

En su discurso inaugural del 4 de marzo de 1845, Polk declaró que consideraba su deber

afirmar y mantener por todos los medios constitucionales el derecho de Estados Unidos a esa parte de nuestro territorio que yace más allá de las montañas Rocallosas. Nuestro derecho al país de Oregón es "claro e incuestionable", y nuestra gente se prepara ya para hacer valer ese derecho ocupando ese territorio con sus esposas e hijos. ${ }^{41}$

${ }^{41}$ James K. Polk, "Inaugural address, march 4 , 1845", Niles' National Register, vol. XVIII, núm. 1,8 de marzo de 1845, p. 3 .
Sin embargo, Polk no decidió de qué manera proceder al respecto sino hasta el verano de 1845 . Aparentemente dentro de un espíritu de continuar los esfuerzos de arbitraje de sus antecesores, Polk estuvo de acuerdo en aceptar una oferta anterior para establecer la frontera en el paralelo 49 pero sin conceder a los británicos derechos de navegación libre por el río Columbia. James Buchanan, el nuevo secretario de Estado de Polk, explicó el cambio de postura del presidente y su disposición a pactar, no obstante su firme posición durante la campaña ("Oregón en su totalidad o nada"), de la siguiente manera: "Él no habría consentido en entregar ninguna parte del territorio de Oregón si no se hubiese visto comprometido, si no es que acorralado, por los actos de sus antecesores." 42

De cualquier manera, la primera oferta de avenencia de Polk fue rechazada por el ministro británico de Relaciones Exteriores en Washington, Richard Pakenham, el 29 de julio de 1845 , sin siquiera habérsela planteado a su gobierno. Polk reaccionó con indignación y le ordenó a Buchanan

imponer y hacer valer nuestro derecho sobre el territorio entero de Oregón desde los $42^{\circ}$ hasta los $54^{\circ} 40^{\prime}$ latitud norte [...] y declarar con claridad que la propuesta que se habia hecho para llegar a un avenimiento sobre el paralelo 49 de la latitud norte había sido hecha,

42 Buchanan a Pakenham, 12 de julio de 1845. Correspondence Relative to... the Oregon Territory, Parliamentary Papers, 1846, folio 1, p. 34, según lo cita Reeves, American 1907, p. 252. 
primero, en deferencia de nuestros antecesores, y segundo, con el ansioso deseo de preservar la paz entre los dos países. Que esa propuesta, hecha por las razones asentadas y dentro de un espíritu liberal de avenencia, había sido rechazada por el ministro británico con un lenguaje, por decir lo menos, poco cortés o respetuoso y, asimismo, sin someter ninguna contrapropuesta por su parte, y que ahora la propuesta era retirada por Estados Unidos, y no debía ya ser considerada como un pendiente a la espera de la consideración del gobierno británico. ${ }^{43}$

Pero Polk siguió abierto a la idea de someter cualquier contrapropuesta "adecuada" al Senado en caso de que los británicos decidieran plantear alguna. Ello abrió la puerta para que los británicos hicieran una propuesta más favorable a sus intereses, sabiendo que Estados Unidos probablemente estaría de acuerdo en fijar la latitud de avenencia en el paralelo 49. A su vez, Polk se colocó en posición de evadir responsabilidades por cualquier acuerdo, trasladando al Senado la responsabilidad de aceptar o rechazar una propuesta cuyo origen era ahora estrictamente británico.

El Senado aconsejó al presidente Polk aceptar la oferta británica para llegar a un acuerdo, que fue planteada muy poco tiempo después, y el 15 de junio de 1846 , finalmente, se firmó el Tratado de Oregón. El tratado establecía la frontera noroeste de Estados Unidos en el paralelo 49 , y concedía que los británicos siguieran siendo los

${ }^{43}$ Polk, Diary, 1952, entrada del martes 26 de agosto de 1845, p. 2.

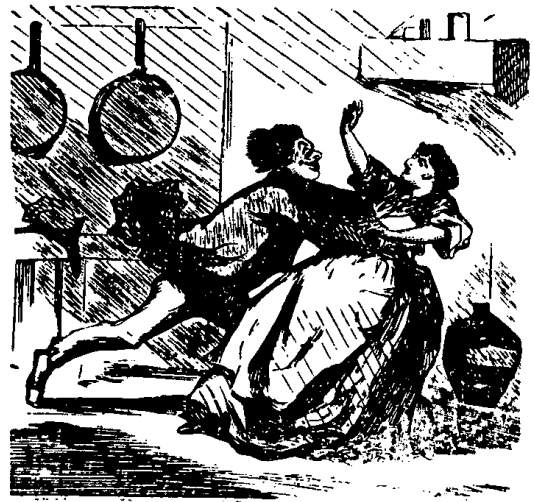

propietarios de la isla de Vancouver y que navegaran con toda libertad por el río Columbia. Para entonces las posibilidades de una guerra con México habían alcanzado una gran importancia, y el debate alrededor de Oregón se diluyó en el discurso nacional una vez que comenzaron las hostilidades con México.

En términos de los principales temas del debate en relación con Oregón, la preocupación dominante antes del tratado de avenencia era si se provocaría una guerra con Gran Bretaña. Figuras políticas como John Calhoun abogaban en favor de una política de "sabia inactividad", alegando que con el tiempo la región de Oregón acabaría formando parte de Estados Unidos, y que una guerra con Gran Bretaña podría terminar en la pérdida del territorio entero. Aunque el temor de empezar una guerra contra Gran Bretaña era virtualmente unánime en todo Es- 
tados Unidos, muchos norteños consideraban que el tratado de Oregón favorecía al Sur, en especial porque había sido firmado después de que el Sur se había asegurado la anexión de Texas. El descontento de los norteños con el resultado de la negociación sobre Oregón también se filtró en el debate sobre la esclavitud en los nuevos territorios. Cuando la cláusula Wilmot, que prohibía la esclavitud en los nuevos territorios, fue presentada en el Congreso el 8 de agosto de 1846 (como anexo al documento propuesto por Polk para destinar 2000000 de dólares para ofrecer un acuerdo de paz a México), las divisiones regionales por el problema de la esclavitud salieron nuevamente a la luz. ${ }^{44}$ Para entonces, no obstante, Estados Unidos había declarado la guerra a México, y la atención del país estaba más concentrada en la tarifa arancelaria $y$ en los asuntos de la guerra que en el tema de la esclavitud.

\section{CONCLUSIÓN: LOS DESAFÍOS PARA POLK}

La controversia regional que prevaleció entre 1844 y 1845 dominó el debate político y definió los temas centrales de la contienda electoral. Los intereses sureños eran la fuerza que guiaba a la política de ese periodo; sin embargo, la combinación de un sistema de partidos que funcionaba como una máquina electoral, especialmente en una época en que el país estaba tan fuerte-

\footnotetext{
44 Para un estudio detallado de los asuntos regionales que orientaron el debate sobre la cláusula Wilmot véase Morrison, Democratic, 1967.
}

mente dividido económica y socialmente, y el surgimiento de una oposición más fuerte que se identificaba con los intereses comerciales del Noreste, operó como una fuerza equilibradora que hizo surgir la necesidad y los medios para un mayor grado de avenencia entre las facciones.

El debate de la tarifa arancelaria reflejaba la división entre los intereses económicos del Norte y del Sur, que en la mayoría de los casos trascendían las posturas partidarias. Sin embargo, la mayor parte de los cismas intrapartidarios eran contenidos por lealtades de partido, aunque no sin controvertidos debates. El debate por la anexión de Texas ilustra la complejidad de los problemas regionales. Los argumentos de "necesidad" y los sentimientos de "destino manifiesto" se veían confrontados persistentemente por la controversia sobre la extensión de la esclavitud. En ambos temas del debate, la agresiva posición de los defensores de los derechos del Sur subrayaba el frágil estado de la Unión.

Los problemas y las fuerzas operantes en el sistema político siguieron siendo en gran medida los mismos durante los siguientes años. Cuando Polk asumió la presidencia a principios de 1845, aceptó la medida que Tyler adoptó para la anexión de Texas, y llevó adelante los planes que habían sido establecidos por su antecesor. El resultado de la lucha por la anexión, con la esclavitud permitida al sur de la línea de avenencia de Missouri, incendió los ánimos de los partidarios de Van Buren, que durante el gobierno de Polk siguieron conformando una fuerza a la que había que tomar en cuenta. 
Al constituir su gabinete, Polk intentó apaciguar a las facciones más descontentas del Partido Demócrata consultando con Van Buren quiénes podrían ser candidatos aceptables para ciertos puestos clave; no obstante, al ceder a las presiones de las facciones antivanburenistas del partido, desechó su consejo e hizo sus propias elecciones, convenciendo así a los seguidores de Van Buren de que los había traicionado en favor de los intereses del Sur. En consecuencia, el malestar dentro de su partido, que se había originado con su propia nominación en 1844 , se intensificó.

La negociación de una tarifa arancelaria más baja fue un proceso largo y complicado, pues los demócratas, incluyendo al vicepresidente Dallas -cuyo estado natal (Pensilvania) se oponía vigorosamente a la propuesta de la ley arancelaria Walker-, se hallaban divididos por los intereses norteños y sureños. Después de incontables modificaciones, el gobierno finalmente sometió la propuesta a la aprobación del Congreso. El debate legislativo duró dos semanas, entre rumores de sobornos ofrecidos para comprar votos. Finalmente, la tarifa Walker fue aprobada en el Senado con un margen de un voto. ${ }^{45}$

El acuerdo de Oregón también colocó en posiciones antagónicas a muchos demócratas del Norte a medida que el asunto se enredó con las divisiones regionales en el seno del partido. Para muchos demócratas del Norte y del Oeste, el tratado negociado con

45 Para una breve descripción del debate por la tarifa arancelaria en 1846 , véase Haynes, $J a$ mes, 1997, pp. 80-82.
Gran Bretaña para fijar la frontera en el paralelo 49 era una señal de que Polk estaba dispuesto a sacrificar los intereses del Norte por los del Sur.

Cuando estalló la guerra con México, el debate incluyó reclamos de que la guerra era resultado de la anexión de Texas que el Sur esclavista había perseguido tan exitosamente. Se alegó que Texas había sido anexado para extender la institución de la esclavitud, y que la guerra con México estaba siendo financiada con el mismo propósito, una vez visto que la adquisición de territorios adicionales en el Suroeste era cada vez más plausible. El amargo debate sobre la cláusula Wilmot, que prohibía la esclavitud en los nuevos territorios, ilustra ese acrecentado conflicto regional. Polk, sin embargo, tuvo éxito en su programa bélico y, a fin de cuentas, alcanzó su meta cuando México cedió California y Nuevo México.

De esa manera, después de sólo 18 meses en el poder, Polk había cumplido tres de sus principales objetivos: había resuelto el problema de Texas y los términos de su anexión; había negociado exitosamente la aprobación de una tarifa arancelaria más baja, y había logrado llegar a un acuerdo en la controversia con Gran Bretaña acerca de Oregón. Y para entonces las perspectivas de lograr su cuarto objetivo, la adquisición de Nuevo México y California, parecían muy favorables. Sus éxitos, a la luz del escenario político en el que había tenido que desenvolverse, eran considerables. No obstante, el carácter regional de la estructura política persistiría, dado que ni la ideología whig ni la demócrata fueron capaces 
de proporcionar los medios necesarios para un acuerdo político que impidiera el estallido de la guerra civil, quince años después de la elección de James K. Polk.

\section{HEMEROGRAFÍA}

-Baltimore American, Baltimore. -Journal of Commerce, Nueva York. -Mercury, Charleston.

-National Intelligencer, Washington. -Niles' National Register, Baltimore.

\section{BibLIOGRAFÍ}

-Ashworth, John, "Agrarians" and "aristocrats": party political ideology in the United States, 1837-1846, Royal Historical Society, Londres, 1983.
-Haynes, Sam W., James K. Polk and the expansionist impulse, Addison Wesley Educational Publishers, Inc., Nueva York, 1997.

-Morrison, Chaplain W., Democratic politics and sectionalism, The University of North Carolina Press, Chapel Hill, Carolina del Norte, 1967.

-Polk, James K., Polk: The diary of the president, 1845-1849, Allan Nevins (ed.), Longmans, Freen y Co., Londres/Nueva York/Toronto, 1952.

-Reeves, Jesse S., American diplomacy under Tyler and Polk, The Johns Hopkins University Press, Baltimore, 1907.

-Rozwenc, Edwin C. y Thomas Bender, The making of american society, Alfred A. Knopf, Inc., 2a. ed., Nueva York, 1972/ 1978 , vol. I, hasta 1877 , p. 480.

Schwarzlose, Richard Allen, Newspapers: a reference guide, Greenwood Press, Nueva York, 1987. 